\title{
Cognitive, Affective, or No Engagement? How Young Adults in Austria Deal with Media Coverage on the EU
}

\author{
Christina Ortner
}

\begin{abstract}
Drawing on qualitative data from a mixed-method study, this paper analyses 30 cases to find out, how and why young adults in Austria engage in media coverage on the EU. The analyses shows that young people react quite differently to media reports on this topic. While some pay attention, actively search for information and intensively deal with EU content (cognitive engagement), others do not follow European affairs but react emotional when they come across it (affective engagement). The third group is characterised by a very low overall level of engagement. Both, intensity and form of engagement depend on young people's satisfaction with EU media coverage, their general relation to information media, politics and the EU and their willingness to make efforts. Finally, the data suggest that political cynicism does not necessarily lead to disengagement, but rather to a more emotional and less constructive form of engagement.
\end{abstract}

KEY WORDS media engagement; audience engagement; political engagement; young people; European Union; EU; media

\section{Introduction}

In 1957 the Treaty of Rome laid the grounds for fundamental changes to the political order in Europe. In the following decades, the mainly economic European Communities developed into a political Union with major competences and a large territory. Today, young people in Europe grow up in a system of multi-level governance (Hooghe and Marks 2001), where decisions taken at a supranational level increasingly influence their lives. To be capable of acting in such a system, they have to engage in politics at several levels including the European. This engagement is not only important for them, but also for the European Union (EU) as a democratic system. If the EU fails to take its future citizens on board its already limited democratic legitimacy will be further weakened.

Given the complexity of the political system, which is hard to understand for ordinary citizens, the multitude of other challenges young people face in their lives, and their limited time and cognitive resources, we cannot assume a permanent high level of participation. However, as Berger suggests, this may not necessarily be required, as long as citizens take

Sociální studia / Social Studies 2/2018. Pp. 55-73. ISSN 1214-813X. 
political action when the circumstances demand it (2009: 345). Between these episodic moments of "manifest political behaviour" (Ekman and Amnå 2012: 289), citizens, however, need to stay connected. In contemporary societies, which face various processes of mediatisation (Couldry and Hepp 2013; Krotz 2014), media are of notable relevance in this context. In traditional mass media as well as online, European issues are widely discussed, allowing young people to keep up with what is going on, draw conclusions, develop their own positions, or express their opinions. In order to stay connected it is, however, not enough to come across these media debates now and then, but to actually engage in them. As Livingstone and Markham showed, active engagement with the news can foster manifest forms of political participation, which is not true for mere news consumption (2008: 14).

Against this background, it is important to get a better understanding of how young people engage in media coverage on the EU. Although there is a rich body of research on the role of media for European integration, there is still little knowledge on this issue. This may be due to the focus on questions of the European public sphere, which resulted in a lack of research on people's reactions to EU media coverage. Besides a number of media effect studies (e.g. Peter 2004; Maier and Rittberger 2008; Vliegenthart et al. 2009; Scharkow and Vogelsang 2010) and a few conceptual papers (e.g. Paus-Hasebrink and Ortner 2007, 2009), research on this topic was for a long time limited to sporadic questions in Eurobarometer surveys. Only recently have there been investigations on citizens' reactions to media coverage of the Euro crisis (Hepp et al. 2012, 2016a, 2016b), on young adults' difficulties in making sense of EU reporting (Ortner 2017) or on the role of media experiences for forming orientations towards the EU (Ortner 2014). When it comes to questions of engagement, we can draw on two articles from Lingenberg $(2006,2010)$. Yet, her findings do not refer to young people and focus on the constitutional debate only.

Given this state of research, this article attempts to take a first step towards a better understanding of young peoples' engagement in media debates on the EU. By conducting a case study of Austria - a country with polarised media coverage and a rather Eurosceptic population - it sheds light on how and why young adults engage, who engages in which ways, and how this relates to overall patterns of media use and political behaviour.

\section{Theoretical framework}

What is engagement in media coverage on the EU?

To fulfil this goal, it is first necessary to clarify what engagement means in the context of political media use. When engaging with media coverage on the EU, young people act in two different roles at the same time, namely as citizens and as media users. Therefore, it makes sense to draw on literature dealing both with political engagement and audience engagement. The notion of political engagement, which according to Dahlgren (2009: 80 ) is often used synonymously for political participation, has been discussed in different disciplines for several decades (see Ekman and Amnå 2012). Traditional understandings mainly focus on conventional political behaviour and therefore do not see media use as relevant. Recently, there has been a shift towards a broader understanding also including 
activities such as following politics in the news (e.g. Spannring 2008: 56; Ekman and Amnå 2012: 295). This builds on the idea that as soon as citizens engage with political media content, they "connect to the public realm in which political issues are being discussed" (Ahva and Hellman 2015: 670) - an assumption that has been investigated by Couldry et al. (2007). While this strand of literature helps us to understand the role of media for political engagement, it cannot give an answer to what it looks like when young people engage with media coverage on the EU. In order to better understand this, we have to look at the notion of audience engagement, which traditionally has been tackled in the field of audience research (Livingstone 2007: 1). However, in this field engagement is used in a wide range of contexts referring to all sorts of audience practices, often without being specified in more detail.

Given this situation, it may be helpful to pin down the core idea of engagement beyond the context of politics or media use. Based on psychological literature, we can perceive engagement as an individual state of a person, which is characterised by activation directed towards a specific object (see Gambettia and Graffigna 2010, or Schaufeli 2013). Thus, engagement in media coverage on the EU can be defined as a state of activation towards media content on European affairs. What it means to be active when dealing with media content has been discussed since the 1970s in the tradition of the "Users and Gratifications" approach. The most prominent classification of audience activities, which had great influence on further debates, was presented by Levy and Windahl in 1984. Only recently, it was adapted by Jungnickel and Schweiger (2014) to suit the conditions of modern media environments. In their adaptation, Jungnickel and Schweiger distinguish between a) communication acts, b) communication motivations, and c) communication intensity. As we are interested in the degree of activation when undertaking media-related activities, we leave aside the first two dimensions and focus on the third, namely communication intensity.

According to Jungnickel and Schweiger (2014), this intensity can refer to the reception as well as to the production of media content. Reception intensity applies to cognitive and affective processes that occur when young people deal with media content, both during and after exposure. It includes aspects of sensing, processing, and interpreting information (on the cognitive level) and emotional reactions (on the affective level). Production intensity refers to the amount of time and cognitive resources people put into the production of media content, e.g. in commenting, liking, or sharing public messages of others or by publishing their own contributions. Finally, we add a third form of communication intensity, namely selection intensity. It describes the degree of consciousness and intentionality of decisions taken, when selecting media content - an aspect that has already been described by Levy and Windahl (1984).

\section{Forms of engagement in media coverage of the EU}

To sum up, we define engagement in media debates on the EU as a personal state of activation towards media content on European issues. Moreover, we consider communication intensity as the core of audience activation. Consequently, the different subdimensions of communication intensity deliver a suitable instrument for identifying different forms of engagement in media coverage of the EU. 
Figure 1: Forms of engagement in media coverage of the EU

\begin{tabular}{|c|c|c|c|}
\hline \multicolumn{4}{|c|}{$\begin{array}{c}\text { Engagement in Media Coverage on the EU } \\
\text { (=Communication Intensity) }\end{array}$} \\
\hline $\begin{array}{c}\text { Motivational } \\
\text { Engagement } \\
\text { (=Selection Intensity) }\end{array}$ & $\begin{array}{c}\text { Cognitive } \\
\text { Engagement } \\
\text { (=Reception Intensity) }\end{array}$ & $\begin{array}{c}\text { Affective } \\
\text { Engagement } \\
\text { (=Reception Intensity) }\end{array}$ & $\begin{array}{c}\text { Contributive } \\
\text { Engagement } \\
\text { (=Production Intensity) }\end{array}$ \\
\hline $\begin{array}{c}\text { Degree of Consciousness } \\
\text { and Intentionality }\end{array}$ & $\begin{array}{c}\text { Amount of Attention } \\
\text { and Elaboration }\end{array}$ & Degree of Intensity & Amount of Effort \\
\hline $\begin{array}{c}\text { Valence: } \\
\text { positive-negative }\end{array}$ & $\begin{array}{c}\text { Valence: } \\
\text { neutral }\end{array}$ & $\begin{array}{c}\text { Valence: } \\
\text { positive- negative }\end{array}$ & $\begin{array}{c}\text { Valence: } \\
\text { positive-negative }\end{array}$ \\
\hline $\begin{array}{c}\text { Indicators: } \\
\text { searching for media } \\
\text { information on the EU, } \\
\text { turning away when } \\
\text { coming across articles } \\
\text { on the EU etc. }\end{array}$ & $\begin{array}{c}\text { Indicators: } \\
\text { paying attention, } \\
\text { making links to pre- } \\
\text { existing knowledge or } \\
\text { attitudes etc. }\end{array}$ & $\begin{array}{c}\text { Indicators: } \\
\text { getting angry or worried } \\
\text { when reading about } \\
\text { the EU, being pleased, } \\
\text { excited, enthusiastic etc. }\end{array}$ & $\begin{array}{c}\text { Indicators: } \\
\text { liking or sharing articles } \\
\text { on the EU, making } \\
\text { comments, publishing } \\
\text { own content etc. }\end{array}$ \\
\hline
\end{tabular}

Figure 1 shows how we apply the concept of communication intensity to our research object by specifying four dimensions of engagement. The first dimension corresponds to the idea of selection intensity and grasps the degree of consciousness and intentionality of contacts young people have with media content on the EU. Young people who actively turn to media content on European affairs or search for information are perceived as more engaged than others who come across it by chance. According to Bilandzic, this aspect is closely linked to motivational aspects (2004), which is why we call it motivational engagement.

The second dimension refers to the amount of attention and elaboration young people invest when dealing with media content on the EU during or after exposure. This form of engagement applies to young people who pay a great deal of attention to EU-related media, reflect on it, link it to what they already know, or draw own conclusions. As this dimension mainly refers to cognitive aspects, we call it cognitive engagement.

The third dimension describes the intensity of emotional reactions young people show when they get into contact with media on European issues and is named affective engagement. It builds on the assumption that young people who react with strong emotions are engaged in media debates on the EU in a more intensive way than those who do not show any feelings. Both cognitive and affective engagement derive from the concept of reception intensity described by Jungnickel and Schweiger (2014), yet describe different facets of the reception process.

Finally, the fourth dimension takes up the idea of production intensity, referring to the effort young people put into publishing their own opinions or reacting to statements of others, e.g. in online platforms or social media. This last dimension is related to activities that contribute to the debate by spreading specific messages or making one's own contributions, which is why we speak of contributive engagement.

All these forms of engagement may range from very low to very high activation. Moreover, they are characterised by their positive, neutral, or negative valence. Although engagement is often conceptualised as a positive relation towards an object, we agree with Latulipe et al. (2011) that it can as well be negative. With regard to affective engagement this 
is quite obvious. We can assume that young people who are angry about what they read about the EU are as activated as those who react enthusiastically. The same is true for motivational engagement, as young people may turn not only towards media content on the EU, but also away. Seen in that way, avoidance is not an indicator of disengagement as Ekman and Amnå (2012: 294) suggest, but a specific form of negative engagement. The contributions of young people to public debates can be neutral or have a positive or negative stance. Merely cognitive engagement is neutral in nature.

\section{Contextualising engagement in media coverage of the EU}

As this article is not only interested in how young adults engage with EU media coverage, but moreover how and why they differ in their behaviour, we have to consider a number of contexts. One reason for differences may lie in the way young people think about the object their engagement refers to. Therefore, we will have a look at their perceptions of media coverage of the EU. This includes a number of aspects such as the relevance of issues tackled, the trustworthiness and quality of information, or the comprehensibility of the debates. As different types of media report on the EU quite differently, it is also important to see in which sources young people encounter the EU. Media use, however, is strongly habitual and shaped by daily routines. Therefore, the way young adults deal with media content on the EU cannot be seen as isolated from their overall ways of approaching media. As young people grow up in comprehensive media environments today, we have chosen an approach by Hasebrink and Domeyer (2012) that focuses on media repertoires as relatively stable individual patterns of media behaviour, including all sorts of media and content. As the EU is mainly tackled within the news we are particularly interested in young peoples' information repertoires (Hasebrink and Domeyer 2010).

However, young adults act not only as media users but likewise as citizens when dealing with media debates on the EU. Therefore, we also take into account their relation to politics in general and the EU in particular by drawing on the concepts of political orientations and participation. According to Niedermayer and Westle, political orientations are "everything people have in their mind with respect to a specific object" (1995: 44). Political participation - in the way we understand it - "involves some "activity" (Dahlgren 2009: 81) and therefore refers to what people do with respect to politics. These activities can either be undirected - e.g. when young people discuss politics with friends or follow politics in the news - or can try to influence political outcomes (Ekman and Amnå 2012: 295). The latter can occur within the structures of representative democracies - e.g. voting, taking part in referenda, contacting politicians, being a member of a party - or outside of this framework - e.g. signing petitions, demonstrating, participating in strikes, supporting NGOs etc. (Spannring 2008: 56; Ekman and Amnå 2012: 289f.). Finally, the ways young people deal both with media and politics are shaped by the challenges of everyday life that force people to carefully use their limited time and resources. 


\section{Methodology}

In order to get a deeper understanding of young adults' engagement with media coverage on the EU a case-based approach (see Gerring 2004) is used, concentrating on a small number $(\mathrm{N}=30)$ of young adults within a single country, namely Austria. Austria entered the EU in 1995 and is characterised by polarised media coverage and a rather Eurosceptic population. It is particularly interesting as it is one of the smaller EU countries situated in the centre of Europe between the East and the West. The small sample of 30 young adults (20-30 years old) allows us to have a closer look at their behaviour, taking into account their individual perspectives and conditions. Therefore, this research is of an explorative nature aiming at generating hypotheses rather than testing them.

The structure of the sample was set a priori according to the principle of heterogeneity (see Flick 2009: 115). The respondents were contacted in various ways (e.g. e-mails, social media, bulletins, newspaper ads, snowball system) with the help of various organisations, companies, and public agencies who have contact with specific groups that were needed to fulfil the sample criteria. As a result, the sample ensures variation regarding education, gender, urbanisation, employment status, age, and professional background (see Figure 2). Therefore, we are able to identify various different forms of behaviour and make assessments of the more or less dominant variants within the sample.

Figure 2: Structure of the sample

\begin{tabular}{|c|c|c|c|c|c|}
\hline & \multicolumn{3}{|c|}{ Educational Groups } & \multirow{2}{*}{$\begin{array}{c}\text { Overall Sample } \\
\mathbf{3 0}\end{array}$} \\
\hline & & High (10) & Middle (10) & Low (10) & \\
\hline \multirow{2}{*}{ Gender } & Male & 5 & 4 & 7 & 16 \\
\hline & Female & 5 & 6 & 3 & 14 \\
\hline \multirow{3}{*}{ Urbanization } & Major Town & 6 & 2 & 3 & 11 \\
\hline & Small Town & 3 & 3 & 1 & 7 \\
\hline & Countryside & 1 & 5 & 6 & 12 \\
\hline \multirow{4}{*}{$\begin{array}{l}\text { Employment } \\
\text { Status }\end{array}$} & Employed & 7 & 8 & 6 & 21 \\
\hline & Unemployed & 2 & 2 & 0 & 4 \\
\hline & Student & 1 & 0 & 2 & 3 \\
\hline & Other & 0 & 0 & 2 & 2 \\
\hline \multicolumn{2}{|l|}{ Age } & $25-28$ & $22-30$ & $21-26$ & $21-30$ \\
\hline \multicolumn{2}{|c|}{ Occupational Field } & \multicolumn{4}{|c|}{ variation within the overall sample, 9 different sectors } \\
\hline
\end{tabular}

The empirical data result from a bigger study on the formation of orientations towards the EU during adolescence (Ortner 2014). It consists of 30 problem-centred interviews complemented by quantitative data from an online questionnaire filled out by the interviewees. In order to systematically link the qualitative and quantitative data at the level of the single cases, profiles of the 30 respondents were prepared. They integrate the statements from the interviews and the online survey (for more detail, see Ortner 2018) and deliver information 
on the respective person's mediated, interpersonal, educational, and direct experiences with the EU, overall patterns of media use, relations to politics and the EU, and life circumstances.

For the purposes of this article, the 30 profiles were reanalysed with a focus on engagement with media coverage of the EU. As a first step, every single profile was looked through to find indicators for how and why this person engages with media content on European issues. Drawing on both theoretical considerations and the structure of the data, a set of categories was developed. Subsequently, the data from all 30 cases were compared category by category to get an overview of the main aspects of the research question. As a second step, the single cases were analysed in more detail to be able to describe individual combinations of motivational, cognitive, affective, and contributive engagement. Some of the patterns found in this process were rather unique, while others applied to more than one person. By doing a comparative analysis, groups of similar cases were identified. Three of these groups represent extreme forms of engagement with media content on the EU and were therefore analysed in more detail, having a closer look at the individual backgrounds of these young people.

\section{Findings}

\section{How and why young Austrians engage}

In doing so, we are able to obtain insights as to how and why young Austrians engage in media debates on the EU, which forms of engagement can be observed, and how young people differ concerning their behaviour. All in all, the results point to a rather low level of engagement across all four dimensions. However, we can find considerable variation within the sample.

\section{Motivational engagement - ways of getting into contact with media debates on the EU}

One indicator for limited engagement in media debates on the EU is the low level of motivational engagement we find within our sample. There are only a few (3 cases) interview partners who consciously turn to media content on the EU on a regular basis. They follow the news about European affairs by reading respective sections in daily newspapers or online news platforms, choosing TV or radio shows on EU-related topics, and frequently searching for information on the EU online. Margit (27 years), for example, reads sections on European politics in both Die Presse and Der Standard - two newspapers of rather high quality - everyday. Now and then, she looks at the rubric EU Theatre in the main tabloid newspaper Kronenzeitung, where letters to the editor on European affairs are published. She moreover listens to the radio show Europajournal on Ö1 - a radio channel of the Austrian public service broadcaster $O R F$ - and searches for European issues using Google. Similar practices of actively turning to the media on European affairs are only evidenced by Edith (27 years) and Simon (28 years). The latter even regularly clicks through the official websites of EU institutions to get detailed information on political initiatives. 
Besides these three people, none of our interviewees shows a high level of motivational engagement. The vast majority (27 cases) does not follow European affairs or regularly search for information on the EU. Therefore, they mainly stumble across this topic in the course of their daily media routines. "I do not specifically look for what is going on in the EU. I rather get to know what I incidentally come across as a consumer of mainstream media", Manfred (28 years) says, and Max (22 years) only notices EU-related topics when they are presented as major headlines. A significant group of people (12 cases) cannot remember any situation when they consciously turned to media reports on European issues. Others do this occasionally, but not on a regular basis (13 cases). Carina (22 years), for example, searched for the number of EU member countries because she needed the information for an exam, and Monika (26 years) sometimes looks up things she is confronted with in conversations. Finally, there is a small group of people (5 cases), who even change the channel, turn the page, or click away when they come across EU-related topics. However, they only occasionally react in this way, depending on the situation. Monika (26 years), for example, turns away when she is displeased by the style of reporting, arguing, or discussing, e.g. in TV talks. Others react with avoidance when they feel offended by what they get to know, e.g. when they touch upon a new EU directive they strongly disagree with. By not confronting with European issues, they try to prevent an unpleasant feeling. "It depends a bit on my actual condition", Sandra (23 years) says. When she is busy or upset, she does not feel ready to confront news that may annoy her.

The low level of motivational engagement, however, does not necessarily result in limited exposure. The vast majority of our interviewees (23 cases) - among them most of the people who are passive or even avoid confrontation (10 out of 14) - report frequent contacts with the EU in the media. "If I read the newspaper I need not read carefully", Alexander (27 years) says. "There is always something on the EU. It appears at least once a day". To some extent, this high visibility may explain why young people do not feel the necessity to become active. "There never was any need", Anna (26 years) says; "what I get to know along the way is enough for me".

\section{Cognitive and affective engagement - ways of dealing with media debates on the EU}

While motivational engagement refers to the way young people get into contact with media debates on the EU, measuring cognitive engagement gives insights into the intensity of dealing with EU-related media content. A first look at the data shows that the number of people with strong cognitive engagement is rather small ( 7 cases). These people frequently pay considerable attention to European issues in the media. Moreover, they describe situations wherein they reflected on the information they were exposed to and set it into a wider context, or evaluated it the light of their own positions. Manfred (28 years), for example, remembers an article on the decision of the EU parliament to vote down the SWIFT agreement - an agreement between the EU and the USA on the transfer of banking data. He reflects on the role of the EU parliament in this process, welcomes its decision, and discusses it in the light of similar debates in other regions of the world. 
However, most of the young people we interviewed (15 cases) only occasionally pay attention to media debates on European affairs. Most of the time, they merely notice some headlines in the daily news. Consequently, they are only roughly aware of the issues currently discussed in the media. "Mostly, I hear about the EU along the way but do not really deal with it", Monika (26 years) says. "Yet, when I come across a buzzword that sounds interesting to me I look at the article". According to our interviewees, this mainly happens when they feel personally affected, when friends or family members are concerned, or when the article has something to do with their job or education. Alexander (23 years), for example, is interested in the European economy and currency because he works in a bank, and Tanja (25 years) takes notice of everything related to the Euro crisis in Greece, because a friend of hers will soon move there. Others, such as Max (22 years), pay attention to topics that are currently widely discussed in the media. In all these cases, however, attention is triggered by the specific policy field or country these articles touch upon, not by the fact that they cover European politics.

Finally, we talked to some people ( 8 cases) who never pay considerable attention to media content on European affairs. "When I read the word 'EU', I think, 'oh well'. Then I look for really important things going on", Timo (28 years) says. He simple does not perceive European politics as relevant. Others do not pay attention because they cannot see how European politics affects their lives, because they have the impression that EU decisions cannot be changed anyway, or because they fundamentally mistrust politics and the media. "Why should I care?" Georg (25 years) asks. "It's all lies anyway". In some cases, limited cognitive engagement results from difficulties in understanding. "I do not read through these articles", Carsten (23 years) says. "I hear it, yet most of the time I do not know what they are about". Pascal (25 years) is even convinced that he would have to read for years to be able to properly understand media coverage of the EU. For a long time, this was also true for Anna (26 years) and Bettina (24 years). Yet, this changed when they learned about the EU in the course of their education. "Now I know what they are talking about in TV news", Anna (26 years) says, which is why she pays more attention.

Another way of engaging in media debates on the EU is through emotional reactions. Interestingly enough, we found only one person who showed moderate positive feelings. Negative emotions - in particular anger - seem to occur more often (8 cases) and can sometimes be quite strong. Georg ( 25 years), for example, is so upset that he uses rude language with a number of swearwords when he describes what he hears about the EU in the media. Strong emotions usually do not arise when young people intensively deal with the issue at hand. For them it is often enough to read a headline to get angry, irritated, or worried. Even if they are aware that their emotions are based on superficial knowledge, these young people do not want to take efforts to get informed. Besides, they fear they will get even angrier when dealing with these issues in more detail. "If I think too much about this I get upset", Derek (27 years) says. "Therefore, I do not bother". As outlined above, negative feelings are unpleasant and can lead to avoidance. Therefore, it is not surprising that all the interviewees who actively turn away from media debates on the EU also show negative emotional reactions. 
Motivational, cognitive, and affective engagement all refer to situations in which young people act as consumers of media content. In the context of online media - in particular social media - young people have the opportunity to go beyond this by stepping into the role of prosumers or producers. By posting, commenting, liking, or sharing they are able to give weight to specific views or feed in new perspectives into the debate on European politics. Although we asked the participants to describe their online behaviour - in particular in social media - and explicitly touched upon questions of politics and the EU, we could not find any indicators of situations where young people made use of this opportunity. Of course, this does not mean that it never happens among our respondents - single acts of liking or sharing are hard to remember - however, none of these practices are meaningful enough to our interviewees to be aware of it. Within our data, we can find several explanations for that. Some do not contribute to the debate because they generally avoid revealing information about themselves online. "I am very conservative when it comes to putting information in the internet", Margit (27 years) explains. Another group regularly posts statements online or reacts to the content of others by commenting, sharing, or liking in social networking sites. However, for them these tools are for private conversations only. "Facebook is there to stay in contact with people", Philip (25 years) says. "I do not put my political attitude in there". Finally, we talked to young adults who deal with politics in social media, yet not with regard to the EU. They join groups with political interests or share political posts they agree with. However, their activities have nothing to do with the EU, either because they are not interested or they simply have not come across such content in social media up to now. "I did not see anything related to the EU so far", Manfred (28 years) says; "it always was on national or local issues".

\section{Typical patterns of engagement among young Austrians}

After we had a look at how and why young adults in Austria engage with media coverage on the EU, we will now describe who engages in which ways. To do this, we compared the 30 single cases across all dimensions of engagement, built groups of similar people and analysed typical patterns in more detail. With regard to motivational engagement we distinguished between positive (turning towards), negative (avoiding), ambivalent (turning towards and avoiding), and no engagement. To grasp how young adults deal with content on the EU during and after exposure, we identified two modes, namely a predominantly cognitive mode and a predominantly affective mode. Within our sample, there is no single person with a balanced relation between cognitive and affective engagement. If cognitive engagement is high, affective engagement is rather low and vice versa. Hence, there is a group that mainly deals with media debates on the EU in a cognitive way and another group that mainly reacts emotionally. Finally, there are people who do not show any considerable level of engagement when coming across media coverage of the EU, i.e. they are neither cognitive nor affective. As we could not find any indicators within our data for contributive engagement, we did not take into account this form of engagement for our comparison. 
Figure 3: Different patterns of engaging with media debates on the EU

\begin{tabular}{|c|c|c|c|c|c|c|}
\hline & \multicolumn{2}{|c|}{$\begin{array}{l}\text { Mainly cognitive } \\
\text { engagement }\end{array}$} & \multicolumn{2}{|c|}{$\begin{array}{l}\text { Mainly affective } \\
\text { engagement }\end{array}$} & \multirow[t]{2}{*}{ Neither nor } \\
\hline & & High & Moderate & High & Moderate & \\
\hline \multirow[b]{2}{*}{$\begin{array}{l}\text { Positive } \\
\text { motivational } \\
\text { engagement } \\
\text { (=Turning to) }\end{array}$} & Regularly & $\begin{array}{l}\text { Edith, } \\
\text { Margit, } \\
\text { Simon }\end{array}$ & & & & \\
\hline & Occasionally & $\begin{array}{l}\text { Manfred, } \\
\text { Manuel, } \\
\text { Philip, } \\
\text { Sara }\end{array}$ & $\begin{array}{c}\text { Anna, } \\
\text { Benedikt, } \\
\text { Max, Bettina, } \\
\text { Tanja, Paul, } \\
\text { Clemens, } \\
\text { Sabine }\end{array}$ & & Carina & \\
\hline \multicolumn{2}{|c|}{$\begin{array}{l}\text { Ambivalent motivational } \\
\text { engagement } \\
\text { (=Turning to and avoiding) }\end{array}$} & & & Monika & Klara & \\
\hline \multicolumn{2}{|c|}{$\begin{array}{l}\text { Negative motivational } \\
\text { engagement } \\
\text { (=Avoiding) }\end{array}$} & & & $\begin{array}{l}\text { Derek, } \\
\text { Georg, } \\
\text { Sandra }\end{array}$ & & \\
\hline \multicolumn{2}{|l|}{ Neither nor } & & $\begin{array}{l}\text { Alexander, } \\
\text { Barbara, } \\
\text { Veronika }\end{array}$ & $\begin{array}{l}\text { Carsten, } \\
\text { Pascal }\end{array}$ & & $\begin{array}{l}\text { Elmar, Jakob, } \\
\text { Sophia, Timo }\end{array}$ \\
\hline
\end{tabular}

Figure 3 shows a matrix including all possible combinations of the described dimensions, as well as the place of every single case within it. As we can see, some combinations apply to several persons, others only to few or even none. The distribution of cases indicates that young adults react to media debates on the EU mainly in a cognitive manner, tend to actively turn to European issues - at least occasionally. On the contrary, interviewees who mainly react emotionally do not follow European affairs in the news, seldom search for information on the EU, or even avoid getting into contact with such information. This indicates that positive motivational engagement is linked to cognitive engagement, while ambivalent or negative motivational engagement goes hand in hand with (negative) affective engagement. Therefore, we can identify two groups that oppose each other and somehow represent extreme patterns of engaging with media debates on the EU: the first group consists of young people with intensive cognitive engagement who actively turn to media content on European affairs. The second group consists of interviewees who react with strong negative emotions, some of them partly avoiding contact. Finally, we will have a look at a third group, namely those who show a very low level of engagement on all dimensions.

\section{Interested and convinced - young adults with strong cognitive engagement}

The first group consists of seven young adults who combine positive motivational engagement with a high level of cognitive engagement. They frequently pay considerable attention to European issues in the media, reflect on the information they get, and consciously turn towards media content about the EU. All of them come across European politics in the media quite often. In the cases of Simon (28 years), Edith (27 years), and Margit 
(27 years), many of these contacts go back to their own initiative. The rest of the group only occasionally turns to EU-related media content but frequently comes across it within their overall use of information media, which is quite extensive. As their information repertoires are characterised by diversity, these young adults obtain news on European politics from different sources, including media of high journalistic quality. Moreover, they have a clear idea of the editorial concept, political stance, and quality of different media sources, which helps them to evaluate the information they get and to choose sources they trust in. None of them has problems in making sense of media coverage on European politics. They all know enough about the EU to be able to understand media reports on this topic. One reason for their high engagement is their strong interest in European and international affairs. Except for one young man (Manuel, 21 years), they all support the EU because they believe in the basic idea of European integration. For them, a political community beyond the nation state is a value in itself, and in addition brings about economic advantages. As they are quite interested in European politics, these people also discuss this topic with friends, colleagues, or family. Also, they learned a lot about the EU in school. Some even had the opportunity to directly get into contact with EU institutions or representatives, e.g. in the course of public talks by EU politicians or school excursions to Brussels.

Manuel (21 years) is the only one in this group who did not learn much about the EU in school and never had any direct contact with EU institutions or representatives. He does not know any person who likes to discuss European affairs with him, because the people around him are not interested in politics. He strongly regrets this. Unlike all other members of this group, he does not clearly support the EU but rather perceives himself as a neutral observer. Strikingly, he is also the only one who started working after primary school. The rest of the group is currently studying or already has a university degree. What Manuel has in common with them is his considerable interest in politics. Like all the others, he wants to know what is going on in politics and is involved in political activities. All the young men and women in this group not only regularly go to the polls, but also visit political events, participate in demonstrations, sign petitions, and are members of parties or involved in trade union activities, political organisations, or student movements. All in all, politics plays an important role in their lives. The following figures sums up the main characteristics of this group.

Figure 4: Main characteristics of group 1 - strong cognitive engagement

\begin{tabular}{|l|l|}
\hline $\begin{array}{l}\text { Group 1: Strong cognitive engagement } \\
\text { Actively turning to EU in the media; intensive cognitive engagement; frequent EU media contacts }\end{array}$ \\
\hline Media use & $\begin{array}{l}\text { Intensive use of information media; competent selection and handling } \\
\text { of information sources; diverse media repertoire; focus on quality media }\end{array}$ \\
\hline EU attitudes & $\begin{array}{l}\text { Considerable interest in and knowledge about the EU; focus on the idea } \\
\text { of a supranational community; mainly supporters (one undecided) }\end{array}$ \\
\hline EU contacts & $\begin{array}{l}\text { Frequent discussions with friends, family, or colleagues on the EU; intensive } \\
\text { educational experiences with the EU; at times direct contacts to EU institutions or } \\
\text { representatives }\end{array}$ \\
\hline Political engagement & Important role of politics in their lives; political activities beyond voting \\
\hline Education & Mainly university students or academics (one primary education) \\
\hline
\end{tabular}




\section{Angry and sceptical - Young adults with strong affective engagement}

The second group is in many respects exactly the opposite of what we just described. These six people only seldom pay attention to media content on the EU and mainly process the information they get in a superficial way. Every now and then, they deal intensively with media content on the EU, yet in an emotional way. All of them remember situations when media reports on the EU provoked strong negative emotions in them. As these emotions are unpleasant, most of them (4 cases out of 6) partly avoid getting into contact with, or having a closer look at EU-related media. Yet, depending on the situation, they may just as well pay attention. Despite their reluctance, these young people often come across the EU in the media. Although they use information media less extensively than the group described above, most of them regularly follow the news and therefore incidentally come into contact with this topic.

When we have a look at the sorts of media they rely on, we can find quite some variation. However, all of them regularly read tabloid newspapers - mainly Kronenzeitung. This is interesting, because some of them express doubts concerning the trustworthiness of this paper. Yet, they nevertheless read it because it does not demand much cognitive effort, is entertaining, its small size is easy to handle, or simply because it lies around at home or at work. Most of them not only mistrust Kronenzeitung, but the media in general. They think media coverage strongly depends on the attitudes of journalists and is manipulated by politicians. "The media are the [...] machine politics works with", Derek (27 years) says. "For sure this is all controlled from above". With regard to media coverage on the EU, they criticise that the media mainly tackle ridiculous topics, such as directives on the shape of bananas or the colour of road markings. Besides, they find media coverage on the EU fragmented, inconsistent, polarised, confusing, and therefore hard to understand. As they lack basic knowledge, they face difficulties in evaluating the diverse and sometimes contradictory information. This makes them feel excluded from the public debate - a feeling they generally have when it comes to European politics.

When asked for their opinion on the EU, nearly all of them express antipathy. All but one (Monika, 26 years) perceive the EU as a bureaucratic organisation that threatens national sovereignty and therefore they clearly oppose it. Some of them discuss their frustration with friends, family, or colleagues. Others simply do not want to be bothered. In school, they did not learn much about the EU, regardless of when they left the educational system. Moreover, most of them have a rather problematic relationship to politics. Although they say that they are not interested, their emotional reactions show that they still care. Except for Georg (25 years), they regularly go to the polls, and many discuss politics with friends or even visit electoral events or write letters to politicians. At the same time, they fundamentally mistrust politicians, do not feel represented, and doubt that democracy works properly. What is true for national politics, applies even more to the European level, which according to them only serves political elites and is far away from the everyday problems of ordinary people. As we can see in Figure 5, these six people either have a primary or secondary educational degree. None of them is studying at university or has an academic degree. 
Figure 5: Main characteristics of group 2 - strong affective engagement

\begin{tabular}{|l|l|}
\hline $\begin{array}{l}\text { Group 2: Strong affective engagement } \\
\text { Occasionally turning to or avoiding the EU in the media; intensive affective engagement; } \\
\text { frequent EU media contacts }\end{array}$ \\
\hline Media use & $\begin{array}{l}\text { Moderate use of information media; focus on boulevard media; mistrust of media } \\
\text { information; problems understanding EU media reports }\end{array}$ \\
\hline EU attitudes & $\begin{array}{l}\text { Low interest in and knowledge about the EU; focus on national sovereignty and EU } \\
\text { bureaucracy; mainly opponents (one undecided) }\end{array}$ \\
\hline EU contacts & $\begin{array}{l}\text { Occasional or no discussions about EU with family, friends, or colleagues; moderate } \\
\text { educational experiences with the EU; no contacts to EU institutions or representatives }\end{array}$ \\
\hline $\begin{array}{l}\text { Political } \\
\text { engagement }\end{array}$ & $\begin{array}{l}\text { Moderate role of politics in their lives; political cynicism; rarely involved in political } \\
\text { activities beyond voting; one does not vote regularly }\end{array}$ \\
\hline Education & Primary or secondary education \\
\hline
\end{tabular}

\section{Unconcerned and indifferent - young adults with very limited engagement}

Finally, there is a third group of people (4 cases), which stands out from the rest of the interview partners. These young adults are characterised by a very low level of engagement in media debates on the EU across all dimensions. They never turn to media content on the EU, seldom pay attention, and cannot remember any situation in which they reacted emotionally. Except for Sophia (27 years), they are rarely in contact with the EU in the media, which results from their limited use of information media. They do not regularly follow the news. Some stumble over the headlines on TV or the radio but pay only limited attention. Others do not even have a TV set and could easily live without the mainstream media. One reason for their limited interest in current affairs lies in their demanding duties in their job, studies, or family. Moreover, they simply do not feel any need to be informed. Beyond the media, they do not deal with European affairs either. Elmar (27 years) and Timo (28 years) sometimes get involved in discussions with friends or family, but do not contribute much to these debates. Although both went to university, they cannot remember learning much about the EU during their education. This is also true for Sophia (27 years), who attended a secondary school, and Jakob (22 years), who finished school at the primary level. None of them ever had any contact with EU institutions or representatives. Although these young people are aware of their limited knowledge, they do not see any reason why they should change this. However, this does not keep them from having an opinion. Expect for Jakob, who is undecided, they are all slightly in favour of European integration. While Jakob does not care much about politics in general, Elmar is strongly interested in societal issues but does not bother about traditional politics. Sophia keeps updated about regional politics, and Timo is only interested in one specific aspect of national politics, namely the shift to the political right in Austria. Interestingly enough, there is great variation with regard to the educational and professional backgrounds in this rather small group. As we can see in Figure 6, we can find all three educational levels within this group of only four people. 
Figure 6: Main characteristics of group 3 - very limited engagement

\begin{tabular}{|c|c|}
\hline \multicolumn{2}{|c|}{$\begin{array}{l}\text { Group 3: Very limited engagement } \\
\text { Never turning to or avoiding the EU in the media; very limited cognitive and affective engagement; } \\
\text { partly frequent, partly rare EU media contacts }\end{array}$} \\
\hline Media use & $\begin{array}{l}\text { Moderate or limited use of media (especially information media); lack of time } \\
\text { and willingness to make efforts to get informed }\end{array}$ \\
\hline EU attitudes & $\begin{array}{l}\text { Low interest in and knowledge about the EU; no distinct perception of what the EU } \\
\text { is about; mainly supporters (one undecided) }\end{array}$ \\
\hline EU contacts & $\begin{array}{l}\text { At times superficial discussions about the EU with friends, family, or colleagues; limited } \\
\text { educational experiences with the EU; no contacts to EU institutions or representatives }\end{array}$ \\
\hline $\begin{array}{l}\text { Political } \\
\text { engagement }\end{array}$ & $\begin{array}{l}\text { Either low interest in politics or focus on few specific issues; activities in public life but } \\
\text { not in traditional politics (except for voting) }\end{array}$ \\
\hline Education & All educational levels \\
\hline
\end{tabular}

Beyond these three groups we can of course find young people with other, less pronounced patterns of engagement in media debates on the EU (see Figure 3). However, the groups we chose somehow represent extreme forms and therefore help to illustrate the main differences and similarities in a concentrated form.

\section{Conclusions}

By comparing different patterns of engagement among selected cases, we have gained insights into how and why young Austrians engage with media coverage on the EU, how they differ concerning their behaviour, and how this may be linked to their overall relation to media and politics. All in all, the results point to a moderate level of engagement, although we can find considerable variation within our sample. Some young adults consciously turn to media content about the EU on a regular basis, frequently pay attention to European issues in the media, and reflect on the information they get. Others do not follow European affairs, and sometimes even turn away when they stumble across the EU, or get angry, irritated or worried. Finally, there is a group of people with an overall low level of engagement. Interestingly enough, none of our interview partners actively contributes to media debates on the EU e.g. by posting, commenting, liking, or sharing content online.

As cognitive and affective engagement seldom go hand in hand, the findings indicate a negative correlation between these two forms of engagement. Therefore, we can easily distinguish between people who deal with media content on the EU in a predominantly cognitive or predominantly affective way. Indicators for motivational engagement can be found in both groups, yet with antithetic valence. While people with predominantly affective engagement tend to avoid getting into contact with the EU in the media, those with high cognitive engagement actively turn towards such content. The latter can, moreover, rely on additional meaningful experiences with EU politics, for instance in school, in private discussions, or through direct contacts with EU institutions or representatives. In contrast, people with low engagement do not compensate for their lack of intensive media contacts in such ways. 
The rather low level of engagement among the majority of interviewees does not necessarily result in limited exposure. Most of our respondents come across the EU in the media quite often, but seldom pay attention. There are several reasons for that: they are not interested in European politics, cannot see how it affects their lives, have the feeling they cannot change things anyway, do not want to make efforts, or simply have other priorities. A low level of engagement can, moreover, result from dissatisfaction with the way the media report. Some criticise media coverage of the EU for having nothing to do with their lives, and because it is polarised, fragmented, inconsistent, confusing, and hard to understand. Attention, however, can increase when young adults learn about the EU in school and are therefore better able to understand media reports. Moreover, young people tend to take notice of information they personally feel affected by. Strong concern, however, not only enhances cognitive engagement but may likewise provoke (negative) emotional reactions.

According to our findings, the intensity and form of engagement is linked to several contexts. On the one hand, an extensive, multifarious, and competent way of dealing with the information media seems to foster cognitive engagement. The same is true for a positive relation to politics in general and the EU in particular. On the other hand, young people who oppose the EU, mistrust politicians and the media, or feel excluded and badly represented often react emotionally to media debates on this topic. This indicates that political cynicism does not necessarily lead to disengagement but rather to a more emotional and less constructive form of engagement. Very low levels of engagement in media debates on the EU, however, can be found among young people who are either not at all involved in traditional politics, who focus on the local or regional level, or who are interested only in specific political issues. What they have in common is that they only make limited use of information media.

To sum up, the mainstream media in Austria seem to be able to reach young adults with news on the EU and therefore help to connect them to the realm of European politics. Yet, they only partly succeed in engaging them in public debates. As young adults cannot see any relevance of European politics for their lives and do not perceive themselves as part of the game, many have no reason for engaging in media debates on the EU or otherwise. Those who do engage and would probably be prepared to take action are mainly supporters of the EU who feel well represented anyway. A different, more emotional, form of engagement is found among opponents of the EU. These young adults feel excluded from politics and therefore perceive themselves as irrelevant. However, they could become important as soon as they decide to take action. As they are angry not only about specific decisions taken at the European level but also oppose the EU as such, their activities would very likely turn against the political system as a whole. Therefore, it is inevitable to address this group of emotionally engaged but disillusioned young adults in the media and beyond.

However, to enhance young adults' engagement in media debates on the EU, additional research is needed. Although this article delivers several insights, the explorative character of its findings demands further empirical testing with a bigger, preferably representative sample. A larger sample could, moreover, help to better understand practices of active contributing to online debates. As opportunities for engaging in media debates online are constantly changing, our findings on this aspect may, to some extent, be outdated. Another 
limitation results from our focus on young adults in Austria. It would certainly be interesting to compare young people in different European countries, taking into account various national backgrounds, including the way the media in different countries report about the EU.

\section{References}

AHVA, Laura and Maria HELLMAN. 2015. "Citizen Eyewitness Images and Audience Engagement in Crisis Coverage". The International Communication Gazette 77(7): 668-681.

BERGER, Ben. 2009. "Political Theory, Political Science, and the End of Civic Engagement". Perspectives on Politics 7(2): 335-350.

BILANDZIC, Helena. 2004. Synchrone Programmauswahl: Der Einfluss formaler und inhaltlicher Merkmale der Fernsehbotschaft auf die Fernsehnutzung. Munich: Reinhard Fischer.

COULDRY, Nick and Andreas HEPP. 2013. "Conceptualising Mediatization: Contexts, Traditions, Arguments." Communication Theory 23(3): 191-202.

COULDRY, Nick, Sonia LIVINGSTONE and Tim MARKHAM. 2007. Media Consumption and Public Engagement: Beyond the Presumption of Attention. London: Palgrave Macmillan.

DAHLGREN, Peter. 2009. Media and Political Engagement: Citizens, Communication and Democracy. Cambridge: Cambridge University Press.

EKMAN, Joakim and Erik AMNÅ. 2012. "Political Participation and Civic Engagement: Towards a New Typology." Human Affairs 22(3): 283-300.

FLICK, Uwe. 2009. An Introduction to Qualitative Research, 4th edition. London: SAGE.

GAMBETTI, Rossella C. and Guendalina GRAFFIGNA. 2010. "The Concept of Engagement." International Journal of Market Research 52(6): 801-826.

GERRING, John. 2004. "What Is a Case Study and What Is It Good for?" The American Political Science Review 98(2): 341-354.

HASEBRINK, Uwe and Hanna DOMEYER. 2010. "Zum Wandel von Informationsrepertoires in konvergierenden Medienumgebungen”. Pp. 49-64 in Die Mediatisierung der Alltagswelt, edited by Maren HARTMANN and Andreas HEPP. Wiesbaden: VS Verlag für Sozialwissenschaften.

HASEBRINK, Uwe and Hanna DOMEYER. 2012. "Media Repertoires as Patterns of Behaviour and as Meaningful Practices: A Multimethod Approach to Media Use in Converging Media Environments." Participations: Journal of Audience \& Reception Studies 9(2): 757-779.

HEPP, Andreas, Swantje LINGENBERG, Anke OFFERHAUS and Anne MOLLEN. 2012. "Europe Beyond the Crisis? Citizens' (Re)actions on the Multi-segmentation of the European Public Sphere." Pp. 69-94 in The European Public Sphere: From Critical Thinking to Responsible Action, edited by Luciano MORGANTI and Léonce BEKEMANS. Brussels: Peter Lang.

HEPP, Andreas, Monika ELSLER, Swantje LINGENBERG and Anke OFFERHAUS. $2016 \mathrm{.}$. “Appropriating Europe: Communication Repertoires, Citizens' European Public Connections and the Euro Crisis." Pp. 141-192 in The Communicative Construction of Europe: Cultures of Political Discourse, Public Sphere, and the Euro Crisis, edited by Andreas HEPP, Monika ELSLER, Swantje LINGENBERG, Anne MOLLEN, Johanne MÖLLER and Anke OFFERHAUS. Houndmills: Palgrave Macmillan.

HEPP, Andreas, Monika ELSLER, Swantje LINGENBERG, Anne MOLLEN, Johanna MÖLLER and Anke OFFERHAUS. 2016b. "Citizens' Online Engagement: The Euro Crisis in Online Forums." Pp. 109-140 in The Communicative Construction of Europe: Cultures of Political Discourse, Public Sphere, and the Euro Crisis, edited by Andreas HEPP, Monika ELSLER, Swantje LINGENBERG, Anne MOLLEN, Johanne MÖLLER and Anke OFFERHAUS. Houndmills: Palgrave Macmillan. 
HOOGHE, Liesbet and Gary MARKS. 2001. Multi-Level Governance and European Integration. Lanham: Rowman \& Littlefield Publisher.

JUNGNICKEL, Karin and Wolfgang SCHWEIGER. 2014. "Publikumsaktivität im 21. Jahrhundert - ein theoriegeleitetes Framework." Pp. 16-40 in Digitale Gesellschaft-Partizipationskulturen im Netz, edited by Jessica EINSPÄNNER-PFLOCK, Mark DANG-AH and Caja THIMM. Münster: LIT Verlag.

KROTZ, Friedrich. 2014. "Mediatization as a Mover in Modernity: Social and Cultural Change in the Context of Media Change.” Pp. 131-162 in Mediatization of Communication, edited by Knut LUNDBY. Berlin: de Gruyter.

LATUliPE, Celine, Erina A. CARROLL and Danielle LOTTRIGE. 2011. "Love, Hate, Arousal and Engagement: Exploring Audience Responses to Performing Arts." Paper presented at the International Conference on Human Factors in Computing Systems. Session Performing Arts. Vancouver, Canada, May 7-12, 2011.

LEVY, Mark and Sven WINDAHL. 1984. "Audience Activity and Gratifications: A Conceptual Clarification and Exploration." Communication Research 11(1): 51-78.

LINGENBERG, Swantje. 2006. "The European Public Sphere and Its Audience: Citizens' Participation in the European Constitutional Debate.” Pp. 52-59 in Démocratie Participative en Europe, edited by Dominique BERTELLI and Julia JEAN-THERRY. Toulouse: Corep.

LINGENBERG, Swantje. 2010. "The Citizen Audience and European Transcultural Public Spheres: Exploring Civic Engagement." Communications 35(1): 45-72.

LIVINGSTONE, Sonia and Tim MARKHAM. 2008. "The Contribution of Media Consumption to Civic Participation.” British Journal of Sociology 59(2): 351-371.

LIVINGSTONE, Sonia. 2007. "Engaging with Media - A Matter of Literacy?" Keynote presentation at the Conference "Transforming Audiences: Identity, Creativity, Everyday Life." Westminster, UK, September 6-7, 2007.

MAIER, Jürgen and Berthold RITTBERGER. 2008. "Shifting Europe's Boundaries: Mass Media, Public Opinion and the Enlargement of the EU." European Union Politics 9(2): 243-267.

NIEDERMAYER, Oskar and Bettina WESTLE. 1995. “A Typology of Orientations.” Pp. 33-50 in Public Opinion and Internationalized Governance, edited by Oskar NIEDERMAYER and Richard SINNOTT. Oxford: Oxford University Press.

ORTNER, Christina. 2014. Wie junge Erwachsene die EU sehen und was die Medien dazu beitragen. Zur Bedeutung medienvermittelter Erfahrungen für die Entwicklung von Orientierungen gegenüber der EU. Baden-Baden: Nomos.

ORTNER, Christina. 2017. "The Communication Deficit of the EU from a Citizens' Perspective: Young People's Difficulties in Making Sense of Media Coverage on the EU.” Pp. 61-81 in Why Europe? Narratives and Counter-narratives of European Integration, edited by Alina BÂRGĂOANU, Raluca BUTUROIU and Loredana RADU. Bern: Peter Lang.

ORTNER, Christina. 2018. "Die Verbindung qualitativer und quantitativer Daten in der Datenauswertung am Beispiel einer triangulativen Studie.” Pp. 293-307 in Auswertung qualitativer Daten: Strategien, Verfahren und Methoden der Interpretation nicht-standardisierter Daten in der Kommunikationswissenschaft, edited by Andreas M. SCHEU. Wiesbaden: Springer VS.

PAUS-HASEBRINK, Ingrid and Christina ORTNER. 2007. "Socially Disadvantaged Groups and their Attitudes towards Europe: A Conceptual Approach.” Medien Journal 31(2): 11-21.

PAUS-HASEBRINK, Ingrid and Christina ORTNER. 2009. "Images of Europe from the Bottom: The Role of Media for the Attitudes towards Europe among Socially Disadvantaged Groups." Pp. 73-97 in Media Agoras: Democracy, Diversity, and Communication, edited by Inaki GARCIA-BLANCO, Sofie VAN BAUWEL and Bart CAMMAERTS. Cambridge: Cambridge Scholars Publishing. 
PETER, Jochen. 2004. “Our Long Return to the Concept of Powerful Mass Media: A Cross-National Comparative Investigation of the Effects of Consonant Media Coverage.” International Journal of Public Opinion Research 16(2): 144-168.

SCHARKOW, Michael and Jens VOGELSANG. 2010. "Effects of Domestic Media Use on European Integration." Communications 35(1): 73-92.

SCHAUFELI, Wilmar B. 2013. "What is Engagement?” Pp. 15-35 in Employee Engagement in Theory and Practice, edited by Catherine TRUSS, Kerstin ALFES, Rick DELBRIDGE, Amanda SHANTZ and Emma SOANE. London: Routledge.

SPANNRING, Reingard. 2008. "Understanding (Non-)Participation: Meanings, Forms and Reasons." Pp. 55-85 in Youth and Political Participation in Europe: Results of the Comparative Study EUYOUPART, edited by Reingard SPANNRING, Günther OGRIS and Wolfgang GAISER. Opladen: Barbara Budrich Publishers.

VLIEGENTHART, Rens, Andreas R.T. SCHUCK, Hajo G. BOOMGAARDEN and Claes H. DE VREESE. 2009. "News Coverage and Support for European Integration 1990-2006." International Journal of Public Opinion Research 20(4): 415-439.

\section{Author}

Christina Ortner works as Professor for Online Communication at the University of Applied Science Upper Austria and teaches qualitative social science at the University of Applied Science Salzburg. She received her PhD degree at the Salzburg Centre of European Studies (SCEUS) with a dissertation on the role of mediated experiences for developing orientations towards the EU among young adults. Prior to that, she worked as Senior Scientist, Lecturer and Research Fellow at the Department of Communications at the University of Salzburg. Contact: christina.ortner@fh-hagenberg.at 